\title{
Analisis Pengaruh PDB dan Rasio Keuangan terhadap Harga Saham Perusahaan Big-Cap Sektor Properti yang Terdaftar di BEI pada Masa Pandemi Tahun 2020
}

\author{
(The Impact of GDP and Financial Ratios toward Stock Prices on Big-Cap Companies of Property \\ Sector Listed on IDX During Pandemic Era in 2020) \\ Monica Seftaviani Sijabat ${ }^{1 *}$, Lia Yuliana ${ }^{2}$ \\ ${ }^{1,2}$ Politeknik Statistika STIS \\ Jl. Otto Iskandardinata No. 64 C Bidara Cina, Jakarta Timur \\ E-mail: monica.seftaviani21@gmail.com
}

\begin{abstract}
ABSTRAK
Pandemi yang terjadi di Indonesia akibat COVID-19 memberikan dampak yang luar biasa bagi pasar modal. Pada tahun 2020, harga saham pada seluruh sektor mengalami fluktuasi yang signifikan. Sektor properti menjadi sektor yang harga sahamnya paling terpuruk pada tahun 2020. Hal ini terlihat dari pergerakan indeks sektor properti yang mengalami trend cenderung menurun. Pergerakan indeks sektor dipengaruhi oleh pergerakan harga saham perusahaan-perusahaan berkapitalisasi besar (Big-Cap). Pada tahun 2020, rata-rata harga saham perusahaan Big-Cap cenderung menurun dibandingkan triwulan IV tahun 2019. Tujuan penelitian ini adalah mengetahui variabel-variabel yang memengaruhi harga saham perusahaan Big-Cap sektor properti tahun 2020. Untuk mengetahui pengaruh PDB, CR, DER, ROE, dan PBV terhadap harga saham perusahaan Big-Cap sektor property, penelitian ini menggunakan analisis regresi data panel. Hasil penelitian ini adalah DER dan ROE signifikan berpengaruh negatif, sedangkan PBV signifikan berpengaruh positif terhadap harga saham perusahaan Big-Cap sektor properti. PDB dan CR tidak memiliki pengaruh yang signifikan terhadap harga saham perusahaan Big-Cap sektor properti. Oleh sebab itu, investor yang berinvestasi pada saham perusahaan Big-Cap sektor properti perlu mempertimbangkan nilai rasio keuangan, khususnya DER, ROE, dan PBV sebelum mengambil keputusan dalam berinvestasi.
\end{abstract}

Kata kunci: harga saham, sektor properti, PDB, rasio keuangan, regresi data panel

\begin{abstract}
Pandemic that occurred in Indonesia due to COVID-19 had a major impact on the capital market. The stock prices of all sectors experienced significant fluctuations in 2020. The property sector is the sector with the lowest share price in 2020. It may be seen from the the property sector index's movement which experienced a downward trend. The movement of the sector index is influenced by the movement of stock prices of large-cap companies (Big-Cap). In 2020 the average share price of Big-Cap companies tends to decrease contrasted with the $4^{\text {th }}$ quarter of 2019. This study aims to determine variables which affect Big-Cap companies stocks prices in the property sector in 2020. To determine the effect of GDP, $C R, D E R, R O E$, and PBV on the share price of Big-Cap companies in the property sector, this study used panel data regression. The results is DER and ROE had a significant negative effect, while PBV had a significant positive effect on the stock price of Big-Cap companies in the property sector. GDP and CR have no significant effect on the stock prices of Big-Cap companies in the property sector. Therefore, investors who invest in shares of Big-Cap companies in the property sector need to consider the value of financial ratios, especially DER, ROE, and PBV before making investment decisions.
\end{abstract}

Keywords: stock prices, property sector, GDP, financial ratio, panel data regression

\section{PENDAHULUAN}

Pandemi yang terjadi di Indonesia pada tahun 2020 akibat Coronavirus Disease-2019 (COVID-19), membuat pemerintah menerapkan suatu kebijakan untuk melakukan pembatasan sosial secara besar-besaran, yaitu Pembatasan Sosial Berskala Besar (PSBB) di daerah dengan kasus COVID-19 yang tinggi. Pemberlakuan PSBB mengganggu aktivitas pelaku kegiatan ekonomi, sehingga memberikan kerugian secara nasional, sektoral, serta individual dan corporate (Hadiwardoyo, 2020). Hal ini dapat tergambar dari terkontraksinya pertumbuhan ekonomi nasional yang terjadi pada triwulan II dan III tahun 2020. Kondisi tersebut memengaruhi seluruh kegiatan ekonomi, tidak terkecuali kegiatan berinvestasi di pasar modal. Terhambatnya aktivitas ekonomi memunculkan sentimen negatif bagi para investor, sehingga aktivitas di pasar modal terganggu. Hal tersebut membuat Indeks Harga Saham Gabungan (IHSG) mengalami keterpurukan, 
dimana selama tahun 2020 telah terjadi tujuh kali trading halt pada bursa. Salah satu sektor yang mengalami pelemahan yang cukup dalam adalah sektor properti. Berdasarkan data publikasi IDX Monthly Statistics pada bulan Desember, sektor properti merupakan sektor yang paling lambat rebound dibandingkan sektor lainnya. Indeks Sektor Properti (PROPERTY) juga mengalami trend yang menurun sepanjang triwulan I-IV tahun 2020.

Sunaryo (2019) menyatakan bahwa kenaikan dan penurunan suatu indeks harga saham bergantung pada pergerakan harga saham-saham berkapitalisasi pasar besar (Big-Cap). Pada periode triwulan I-IV tahun 2020, rata-rata harga saham perusahaan dengan kapitalisasi pasar yang besar mengalami fluktuasi dan penurunan yang cukup signifikan dibandingkan dengan triwulan IV tahun 2019. Menurunnya harga saham sektor properti pada masa pandemi COVID-19 ini dapat menjadi sinyal adanya ketidakpercayaan investor pada sektor ini. Padahal Santoso (2005) menyatakan bahwa sektor properti adalah sektor investasi yang penting karena dapat memberikan sinyal jatuh atau bangunnya perekonomian negara. Investasi pada sektor ini juga dianggap menjanjikan karena kebutuhan terhadap properti akan terus bertambah, mengingat besarnya jumlah penduduk di Indonesia dan tingginya tingkat pertumbuhan penduduk di Indonesia. Melihat peluang pasar yang begitu besar, seharusnya sektor ini dapat tumbuh dengan pesat. Sektor properti di Indonesia ini juga menunjukkan pelemahan sepanjang triwulan I-IV tahun 2020 berdasarkan survei harga properti residensial (SHPRK) dan komersial (PPKom) yang dilakukan oleh Bank Indonesia (BI), serta laju pertumbuhan triwulanan PDB (y-oy) berdasarkan lapangan usaha real estate dan konstruksi.

Melihat kondisi sektor properti pada masa pandemi COVID-19 yang telah dijelaskan pada paragraf sebelumnya, investor harus lebih hati-hati dalam berinvestasi pada sektor ini. Investor sebaiknya melakukan analisis sebelum memutuskan untuk berinvestasi agar keuntungan yang diperoleh lebih maksimal. Salah satu caranya adalah dengan analisis fundamental (Jones, 2012:348). Penelitian ini menggunakan regresi data panel sebagai metode analisisnya karena metode tersebut dapat mengakomodasi bentuk data gabungan antara crosssection dan time-series. Alwi (2008) dalam Zulfikar (2016) mengemukakan bahwa terdapat faktor-faktor yang dapat memengaruhi harga saham, yaitu faktor ekonomi makro dan faktor internal perusahaan yang dapat diukur melalui kinerja perusahaan, salah satunya yaitu rasio keuangan. Penelitian yang dilakukan oleh Azmy, A. \& Lestari, A. (2019) memberikan hasil, yaitu DER dan ROE berpengaruh positif dan signifikan, sedangkan CR tidak berpengaruh terhadap harga saham perusahaan properti dan real estate. Selain itu, Rahmatullah, M. B., Ahmad, I. S., dan Rahayu, S. P. (2019) menyatakan bahwa PBV dan CR signifikan berpengaruh positif, sedangkan ROE dan DER signifikan berpengaruh negatif terhadap harga saham sektor konstruksi bangunan, properti, dan real estate. Penelitian lain dilakukan oleh Susanti, R. A. \& Santoso, B. H. (2019) yang memberikan hasil PDB signifikan berpengaruh positif terhadap IHS sektor properti dan real estate. Terdapat perbedaan hasil pada beberapa penelitian sebelumnya, sehingga penelitian mengenai hubungan antara kinerja keuangan perusahaan dan PDB pada tahun 2020 perlu dikaji lebih lanjut. Tujuan dari penelitian ini, yaitu:

1. Menggambarkan kondisi harga saham perusahaan-perusahaan Big-Cap sektor properti, PDB, dan rasio keuangan perusahaan (CR, DER, ROE, dan PBV)

2. Mengetahui pengaruh PDB dan rasio keuangan perusahaan (CR, DER, ROE, dan PBV) terhadap harga saham perusahaan-perusahaan Big-Cap sektor properti pada triwulan I-IV tahun 2020.

Berdasarkan penelitian-penelitian terdahulu yang telah dijabarkan sebelumnya, hipotesis penelitian yang diajukan adalah PDB, CR, ROE, dan PBV berpengaruh positif dan signifikan, sedangkan DER berpengaruh negatif dan signifikan terhadap harga saham perusahaan Big-Cap sektor properti.

\section{METODE}

\section{Landasan Teori}

\section{A. Saham}

Tandelilin (2010) menyatakan bahwa saham adalah surat bukti kepemilikan aset-aset perusahaan yang menerbitkan saham. Saham perusahaan yang go public di Bursa Efek Indonesia (BEI) dapat diklasifikasikan berdasarkan kapitalisasi pasarnya. Nilai kapitalisasi pasar diperoleh dari mengalikan harga pasar, yaitu harga penutupan (closing price), dengan jumlah seluruh saham yang beredar. Ahman dan Indriani (2007), serta Azis, Minarti, dan Nadir (2015) mengklasifikasikan saham perusahaan menurut kapitalisasi pasarnya menjadi tiga kategori, yaitu Big-Cap (kapitalisasi di atas lima triliun rupiah), Mid-Cap (kapitalisasi diantara satu sampai dengan lima triliun rupiah), dan Small-Cap (kapitalisasi di bawah satu triliun rupiah). 
Kinerja perusahaan dapat diukur melalui analisis laporan keuangan, dimana salah satu tekniknya adalah dengan menggunakan analisis rasio keuangan. Rasio keuangan yang dapat digunakan dalam analisis antara lain:

1. Current Ratio (CR)

Kasmir (2017:134) menjelaskan bahwa "rasio lancar (current ratio) merupakan rasio untuk mengukur kemampuan perusahaan dalam membayar kewajiban jangka pendek atau utang yang segera jatuh tempo pada saat ditagih secara keseluruhan".

$$
\text { Current Ratio }(C R)=\frac{\text { Aktiva lancar }}{\text { Utang lancar }} \times 100
$$

2. Debt to Equity Ratio (DER)

Kasmir (2017:157) menyatakan bahwa "debt to equity ratio merupakan rasio yang digunakan untuk menilai utang dengan ekuitas".

$$
\text { Debt to Equity Ratio }(D E R)=\frac{\text { Total utang }}{\text { Total ekuitas }} \times 100
$$

3. Return on Equity (ROE)

Kasmir (2017) menyebutkan bahwa rasio ini dapat menunjukkan efisiensi perusahaan dalam menggunakan modal sendiri.

$$
\text { Return on Equity }(R O E)=\frac{\text { Laba setelah pajak }}{\text { Total ekuitas }} \times 100
$$

4. Price to Book Value (PBV)

Franita (2018) menyatakan bahwa PBV dapat menggambarkan seberapa berhasil suatu perusahaan menciptakan nilai perusahaan tersebut relatif terhadap modal yang diinvestasikan.

$$
P B V=\frac{\text { Harga saham } x \text { Jumlah saham beredar }}{\text { Total ekuitas }}
$$

B. Produk Domestik Bruto (PDB)

Tandelilin (2010) menyatakan bahwa Produk Domestik Bruto (PDB) adalah ukuran produksi barang dan jasa total suatu negara. Peningkatan PDB merupakan sebuah sinyal positif bagi investor karena hal tersebut menunjukkan adanya peningkatan daya beli konsumen sehingga permintaan terhadap produk perusahaan dapat meningkat. Penelitian ini menggunakan PDB Atas Dasar Harga Konstan (ADHK).

C. Analisis Regresi Data Panel

Model regresi data panel adalah regresi yang dilakukan dengan menggunakan data panel, dimana data panel adalah gabungan data cross-section dan time-series (Widarjono, 2018). Berdasarkan asumsi error term, intercept, dan slope coefficient yang tetap atau berubah antarindividu, antarwaktu, atau keduanya, terdapat tiga model yang dapat digunakan dalam regresi data panel, yaitu:

1. Common Effects Model (CEM)

CEM tidak memperhatikan perbedaan individu dan waktu, sehingga setiap individu memiliki intercept dan slope yang sama pada semua periode waktu. Model ini menggunakan Ordinary Least Squares (OLS) dalam proses estimasinya. Bentuk CEM secara umum adalah sebagai berikut.

$$
y_{i t}=\alpha+\boldsymbol{x}_{i t}^{\prime} \boldsymbol{\beta}+\varepsilon_{i t}, \quad i=1, \ldots, N ; \quad t=1, \ldots, T
$$

2. $\quad$ Fixed Effects Model (FEM)

Model ini memperhatikan perbedaan intercept antarindividu, tetapi intercept masing-masing individu tersebut tidak bervariasi antarwaktu. Greene (2003) menyatakan bentuk dari FEM adalah sebagai berikut.

$$
y_{i t}=\alpha_{i}+\boldsymbol{x}_{i t}^{\prime} \boldsymbol{\beta}+\varepsilon_{i t}, \quad i=1, \ldots, N ; \quad t=1, \ldots, T
$$

3. Random Effects Model (REM)

REM merupakan model yang mengestimasi variabel gangguan (error) dalam data panel yang mungkin saling terhubung antarwaktu dan antarindividu. Intercept diasumsikan sebagai variabel random. Greene (2003) menyatakan bentuk dari REM adalah sebagai berikut.

$$
y_{i t}=\alpha+\boldsymbol{x}_{i t}^{\prime} \boldsymbol{\beta}+\eta_{i t}, \eta_{i t}=u_{i}+\varepsilon_{i t}, \quad i=1, \ldots, N ; \quad t=1, \ldots, T
$$




\section{Kerangka Pikir}

Pergerakan harga saham suatu perusahaan dapat dipengaruhi oleh berbagai hal, seperti kondisi ekonomi makro dan keadaan perusahaan. Penelitian ini membatasi penggunaan variabel, sehingga hanya PDB dan beberapa rasio keuangan perusahaan saja yang digunakan. Oleh sebab itu, kerangka pikir dari penelitian ini adalah PDB, CR, DER, ROE, dan PBV memengaruhi harga saham atau dapat digambarkan oleh gambar 1.

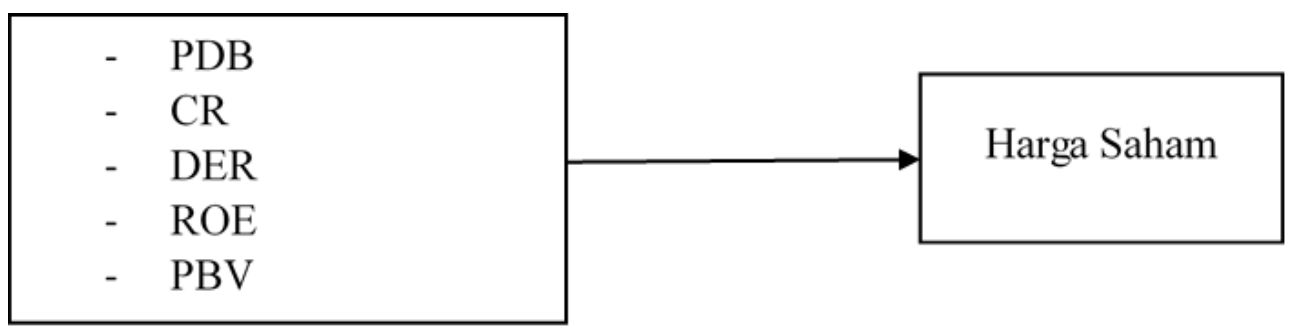

Gambar 1. Kerangka pikir

\section{Cakupan Penelitian}

Penelitian ini menggunakan teknik purposive sampling, dimana kriteria yang digunakan dalam memilih perusahaan properti untuk penelitian ini adalah sebagai berikut.

1. Perusahaan Big-Cap sektor properti yang terdaftar di BEI pada periode I-IV tahun 2020 secara konsisten (tidak mengalami delisting)

2. Laporan keuangan perusahaan tersedia secara lengkap dan dipublikasikan paling lambat tanggal 30 April 2021, sehingga dapat digunakan dalam perhitungan rasio keuangan yang dibutuhkan dalam penelitian

3. Saham perusahaan tersebut aktif diperjualbelikan pada periode penelitian

Berdasarkan beberapa kriteria tersebut, perusahaan properti yang terpilih adalah sebanyak 12 perusahaan. Penelitian ini menggunakan data sekunder yang bersumber dari BEI, yang meliputi laporan IDX Quarterly Statistics dan Laporan Keuangan Perusahaan, serta publikasi BPS. Variabel-variabel yang digunakan dalam penelitian ini dan satuannya adalah harga saham penutupan dalam bentuk ln (persen), PDB dalam bentuk $\ln$ (persen), CR (persen), DER (persen), ROE (persen), dan PBV.

\section{Metode Analisis}

Analisis yang dilakukan pada penelitian ini mencakup analisis deskriptif untuk menggambarkan secara umum karakteristik variabel-variabel yang digunakan, serta analisis inferensia dengan metode regresi data panel untuk melihat pengaruh PDB, CR, DER, ROE, dan PBV terhadap harga saham perusahaan-perusahaan Big-Cap sektor properti selama periode triwulan I-IV tahun 2020.

Tahapan pertama dalam analisis dengan regresi data panel adalah melakukan pemilihan model regresi data panel terbaik, yaitu pemilihan antara CEM, FEM, atau REM, dapat dilakukan dengan menggunakan cara formal. Cara ini menggunakan tiga pengujian, yaitu uji Chow, uji BP-Lagrange Multiplier, dan uji Hausman.

1. Uji Chow

Uji ini digunakan untuk memilih model terbaik antara FEM atau CEM dengan melihat apakah ada perbedaan intercept antarindividu. Jika di dalam model terdapat perbedaan intercept, maka FEM tepat untuk digunakan.

Hipotesis yang digunakan adalah sebagai berikut.

$H_{0}: \alpha_{1}=\alpha_{2}=\cdots=\alpha_{N}=\alpha$

$H_{1}$ : Minimal terdapat satu $\alpha_{i}$ yang berbeda

Statistik uji yang digunakan, yaitu:

$$
\begin{aligned}
& F_{\text {hitung }} \\
& =\frac{(R R S S-U R S S) /(N-1)}{U R S S /(N T-N-K)} \sim F_{(N-1, N T-N-K)}
\end{aligned}
$$

Keterangan:

$\mathrm{K}$ : jumlah variabel independen

$\mathrm{N}$ : jumlah individu (cross-section)

$\mathrm{T}$ : jumlah periode waktu (time-series) 
RRSS: restricted residual sums of squares yang berasal dari CEM

URSS: unrestricted residual sums of squares yang berasal dari FEM

Jika nilai $F_{\text {hitung }}$ lebih besar dari $F_{(N-1, N T-N-K)}$ pada tingkat signifikansi yang ditentukan atau $p$-value lebih kecil dari tingkat signifikansi yang ditetapkan, maka $H_{0}$ ditolak, sehingga model yang lebih baik untuk digunakan adalah FEM.

2. Uji Brusch-Pagan Lagrange Multiplier (BP-LM test)

Uji ini dilakukan untuk memilih model terbaik antara CEM atau REM dengan melihat sifat varians residual pada CEM apakah bersifat acak atau tidak. Jika di dalam model terdapat varians residual yang bersifat random, maka REM tepat untuk digunakan.

Hipotesis yang digunakan adalah sebagai berikut.

$H_{0}: \sigma_{u}^{2}=0$ (varians residual pada CEM tidak bersifat random)

$H_{1}: \sigma_{u}^{2} \neq 0$ (varians residual pada CEM bersifat random)

Statistik uji yang digunakan, yaitu:

Keterangan:

$$
L M=\frac{N T}{2(T-1)}\left[\frac{\sum_{i=1}^{N}\left(\sum_{t=1}^{T} \hat{u}_{i t}\right)^{2}}{\sum_{i=1}^{N} \sum_{t=1}^{T} \hat{u}_{i t}^{2}}-1\right]^{2} \sim \chi_{(K)}^{2}
$$

$\hat{u}_{i t}$ : residual pada CEM

Jika nilai $L M$ lebih besar dari $\chi_{(K)}^{2}$ pada tingkat signifikansi yang ditentukan atau nilai p-value lebih kecil dari tingkat signifikansi yang ditentukan, maka $H_{0}$ ditolak, sehingga model yang lebih baik untuk digunakan adalah REM.

3. Uji Hausman

Pemilihan model terbaik antara FEM atau REM dilakukan dengan cara melihat apakah ada korelasi antara error dengan variabel independen atau tidak. Jika terdapat korelasi antara error dengan variabel independen, maka FEM tepat untuk digunakan.

Hipotesis yang digunakan adalah sebagai berikut.

$H_{0}: E\left(u_{i} \mid X_{i t}\right)=0$ (tidak ada korelasi atau hubungan antara cross section error dan satu atau lebih variabel independen)

$H_{1}: E\left(u_{i} \mid X_{i t}\right) \neq 0$ (ada korelasi atau hubungan antara cross section error dan satu atau lebih variabel independen)

Statistik uji yang digunakan, yaitu:

$$
m=\hat{q}^{\prime}[\operatorname{Var}(\hat{q})]^{-1} \hat{q} \sim \chi_{(K)}^{2}
$$

dimana

$$
\hat{q}=\left[\widehat{\boldsymbol{\beta}}_{F E M}-\widehat{\boldsymbol{\beta}}_{R E M}\right]
$$

Keterangan:

$\widehat{\boldsymbol{\beta}}_{F E M}$ : Matriks estimasi slope berordo $K \times 1$ pada FEM

$\widehat{\boldsymbol{\beta}}_{R E M}$ : Matriks estimasi slope berordo $K \times 1$ pada REM

Jika nilai $m$ lebih besar dari $\chi_{(K)}^{2}$ pada tingkat signifikansi yang ditentukan atau nilai p-value lebih kecil dari tingkat signifikansi yang ditentukan, maka $H_{0}$ ditolak, sehingga model yang lebih baik untuk digunakan adalah FEM.

Selanjutnya, dilakukan pengujian pada matriks variance-covariance saat CEM atau FEM terpilih sebagai model yang terbaik. Terdapat dua uji yang dapat dilakukan, yaitu:

1. Lagrange Multiplier Test (LM Test)

Uji ini dilakukan untuk mengetahui apakah residual bersifat heteroskedastis atau homoskedastis.

Hipotesis yang digunkan adalah sebagai berikut.

$H_{0}: \sigma_{i}^{2}=\sigma^{2}$ untuk $i=1,2, \ldots, N$

$H_{1}$ : minimal ada satu $\sigma_{i}^{2} \neq \sigma^{2}$ 
Statistik uji yang digunakan, yaitu:

$$
L M=\frac{T}{2} \sum_{i=1}^{N}\left[\frac{\hat{\sigma}_{i}^{2}}{\hat{\sigma}^{2}}-1\right]^{2} \sim \chi_{(N-1)}^{2}
$$

Keterangan:

$\hat{\sigma}_{i}^{2}$ : estimasi varians residual individu ke-i

$\hat{\sigma}^{2}$ : estimasi RSS FEM

Jika nilai $L M$ lebih besar dari $\chi_{(N-1)}^{2}$ pada tingkat signifikansi yang ditentukan, maka $H_{0}$ ditolak, sehingga struktur matriks variance-covariance residual bersifat heteroskedastis.

2. $\lambda_{L M}$ Test

Pengujian ini dilakukan untuk melihat apakah struktur matriks variance-covariance residual individu berkorelasi antarindividu (ada cross-sectional correlation) atau tidak.

Hipotesis yang digunakan adalah sebagai berikut.

$H_{0}: \operatorname{cov}\left(\mu_{i}, \mu_{j}\right)=0$ (residual antarindividu tidak berkorelasi)

$H_{1}: \operatorname{cov}\left(\mu_{i}, \mu_{j}\right) \neq 0$ (residual antarindividu berkorelasi)

Statistik uji yang digunakan, yaitu:

$$
\lambda_{L M}=T \sum_{i=2}^{N} \sum_{j=1}^{i=1} r_{i j}^{2} \sim \chi_{\left(\frac{N(N-1)}{2}\right)}^{2}
$$

Keterangan:

$r_{i j}^{2}:$ koefisien korelasi ke-ij

Jika nilai $\lambda_{L M}$ lebih besar dari $\chi_{\left(\frac{N(N-1)}{2}\right)}^{2}$ pada tingkat signifikansi yang ditentukan, maka $H_{0}$ ditolak. Oleh sebab itu, dapat disimpulkan bahwa terdapat korelasi antarindividu.

Setelah model terpilih, dilakukan uji asumsi klasik pada model yang terpilih. Jika CEM atau FEM dengan metode estimasi OLS adalah model terbaik, pemeriksaan asumsi klasik yang perlu dilakukan adalah asumsi homoskedastisitas, nonmultikolinieritas, dan normalitas. Sedangkan, jika CEM atau FEM dengan metode estimasi FGLS, serta REM yang terpilih, pemeriksaan asumsi klasik yang perlu dilakukan adalah asumsi nonmultikolinieritas dan normalitas saja.

1. Uji Homoskedastisitas

Asumsi ini berarti varians residual pada model regresi bersifat konstan. Keadaan varians variabel residual yang tidak konstan disebut dengan heteroskedatisitas (Widarjono, 2018). Salah satu metode pengujian asumsi homoskedastisitas pada regresi data panel adalah Lagrange Multiplier test.

Hipotesis yang digunakan adalah sebagai berikut.

$H_{0}: \sigma_{i}^{2}=\sigma^{2} \quad ; i=1,2, \ldots, N$

$H_{1}$ : minimal ada satu $\sigma_{i}^{2} \neq \sigma^{2}$

Statistik uji yang digunakan, yaitu:

$$
L M=\frac{T}{2} \sum_{i=1}^{N}\left[\frac{\hat{\sigma}_{i}^{2}}{\hat{\sigma}^{2}}-1\right]^{2} \sim \chi_{(N-1)}^{2}
$$

Keterangan:

$\hat{\sigma}^{2}$ : varians residual persamaan sistem

$\hat{\sigma}_{i}^{2}$ :varians residual individu (cross-section) ke-i

Jika pada tingkat signifikansi yang ditentukan, nilai $L M$ lebih besar dari nilai $\chi_{(N-1)}^{2}$, maka $H_{0}$ ditolak. Oleh sebab itu, dapat dikatakan bahwa varians residual tidak konstan atau heteroskedastis.

2. Uji Normalitas

Uji normalitas digunakan untuk mengetahui normal atau tidaknya distribusi error pada model . Salah satu uji normalitas yang dapat digunakan adalah uji Jarque-Bera (JB test).

Hipotesis yang digunakan adalah sebagai berikut. 


$$
\begin{aligned}
& H_{0}: \varepsilon_{i t} \sim N\left(0, \sigma^{2}\right) \\
& H_{1}: \varepsilon_{i t} \times N\left(0, \sigma^{2}\right)
\end{aligned}
$$

Statistik uji yang digunakan, yaitu:

$$
J B=n\left[\frac{S^{2}}{6}+\frac{(C-3)^{2}}{24}\right] \sim \chi_{(2)}^{2}
$$

Keterangan:

$\mathrm{n}$ : sample size (ukuran sampel)

S: skewness coefficient (nilai kemencengan)

C: kurtosis coefficient (nilai kerucingan)

Keputusan hasil pengujian diperoleh dengan membandingkan nilai $J B$ dan nilai tabel $\chi_{(2)}^{2}$ pada tingkat signifikansi yang ditentukan atau dengan membandingkan $p$-value dan tingkat signifikansi yang telah ditetapkan. Jika hasil pengujian adalah gagal tolak $H_{0}$, error berdistribusi normal.

3. Pemeriksaan Asumsi Nonmultikolinieritas

Multikolinieritas merupakan hubungan linier antarvariabel independen di dalam model regresi (Widarjono, 2018). Masalah multikolinieritas dalam model dapat ditunjukkan melalui nilai VarianceInflating Factor (VIF). Sebagai rule of thumb, Gujarati (2004) menyatakan bahwa nilai VIF dikatakan tinggi jika nilai VIF lebih dari 10.

Keterangan:

$$
V I F_{j}=\frac{1}{\left(1-R_{j}^{2}\right)} \quad ; j=1,2, \ldots, K
$$

$R_{j}^{2}$ : koefisien determinasi dari variabel penjelas ke-j terhadap variabel penjelas lainnya

Setelah seluruh asumsi terpenuhi, dilakukan uji keberartian model dapat dilakukan melalui:

1. Koefisien determinasi

Widarjono (2018) menyatakan bahwa koefisien determinasi merupakan konsep yang digunakan untuk mengukur seberapa baik variabel bebas dalam menjelaskan variabel terikat. Pada penelitian ini, digunakan nilai Adjusted R-squared sebagai koefisien deeterminasi.

$$
\bar{R}^{2}=1-\left(1-R^{2}\right) \frac{(N T-1)}{(N T-N-k)}
$$

Keterangan:

$\bar{R}^{2}:$ Adjusted $R^{2}$

$k$ : jumlah parameter dalam model termasuk intercept

2. F Test (Uji simultan)

F test merupakan sebuah pengujian yang dilakukan untuk mengetahui apakah seluruh variabel bebas memengaruhi variabel terikat secara bersamaan (simultan).

Hipotesis yang digunakan adalah sebagai berikut.

$H_{0}: \beta_{1}=\beta_{2}=\cdots=\beta_{K}=0$

$H_{1}$ : minimal terdapat satu nilai $\beta_{j} \neq 0 ; j=1,2, \ldots, K$

Statistik uji yang digunakan, yaitu:

$$
F_{\text {hitung }}=\frac{R^{2} /(N+K-1)}{\left(1-R^{2}\right) /(N T-N-K)} \sim F_{((N+K-1),(N T-N-K))}
$$

Keterangan:

$R^{2}$ : koefisien determinasi

Jika pada tingkat signifikansi tertentu, nilai $F_{\text {hitung }}$ lebih besar dari nilai $F_{((N+K-1),(N T-N-K))}$ pada tingkat signifikansi yang ditentukan, maka $H_{0}$ ditolak. Oleh sebab itu, dapat dikatakan bahwa minimal terdapat satu variabel bebas yang signifikan memengaruhi variabel terikat. 
3. $\mathrm{t}$ Test (Uji parsial)

Uji parsial ( $\mathrm{t}$ test) merupakan sebuah uji yang dilakukan untuk mengetahui signifikansi pengaruh setiap variabel bebas terhadap variabel terikat secara parsial, baik secara positif, maupun negatif.

Hipotesis yang digunakan adalah sebagai berikut.

a. Uji parsial satu arah positif

$H_{0}: \beta_{j}=0 ; j=1,2, \ldots, K$

$H_{1}: \beta_{j}>0 ; j=1,2, \ldots, K$

$H_{0}$ ditolak saat $t_{\text {hitung }}>t_{(N T-N-K)}$ pada tingkat signifikansi yang ditentukan.

b. Uji parsial satu arah negatif

$H_{0}: \beta_{j}=0 \quad ; j=1,2, \ldots, K$

$H_{1}: \beta_{j}<0 \quad ; j=1,2, \ldots, K$

$H_{0}$ ditolak saat $t_{\text {hitung }}<-t_{(N T-N-K)}$ pada tingkat signifikansi yang ditentukan.

Statistik uji yang digunakan, yaitu:

$$
t_{\text {hitung }}=\frac{\widehat{\beta}_{J}}{\operatorname{se}\left(\widehat{\beta}_{J}\right)} \sim t_{(N T-N-K)}
$$

Keterangan:

$\widehat{\beta}_{\jmath}$ : estimasi parameter ke-j

se $\left(\widehat{\beta}_{J}\right)$ : standar error dari estimasi parameter ke-j

Model penelitian yang digunakan pada penelitian ini adalah sebagai berikut.

$$
\text { lnHargaSaham }_{i t}=\alpha_{i}+\beta_{1} \operatorname{lnPDB_{t}}+\beta_{2} C R_{i t}+\beta_{3} D E R_{i t}+\beta_{4} R O E_{i t}+\beta_{5} P B V_{i t}+\varepsilon_{i t}
$$

\begin{tabular}{|c|c|}
\hline$\alpha_{i}$ & $=$ intercept individu ke-i \\
\hline$\beta_{K}$ & $=$ koefisien regresi variabel independen ke-K \\
\hline $\operatorname{HargaSaham}_{i t}$ & = variabel harga saham perusahaan ke-i pada waktu ke-t (persen) \\
\hline $\begin{array}{l}P D B_{t} \\
C R_{i+}\end{array}$ & $\begin{array}{l}=\text { variabel PDB waktu ke-t } \\
=\text { variabel CR perusahaan ke-i pada waktu ke-t }\end{array}$ \\
\hline $\begin{array}{l}D N_{i t} \\
D E R_{i t}\end{array}$ & = variabel DER perusahaan ke-i pada waktu ke-t \\
\hline$R O E_{i t}$ & $=$ variabel ROE perusahaan ke-i pada waktu ke-t \\
\hline$P B V_{i t}$ & $=$ variabel PBV perusahaan ke-i pada waktu ke-t \\
\hline & $=$ individu/perusahaan $(1,2, \ldots, 12)$ \\
\hline & $=$ waktu (triwulan I-IV tahun 2020) \\
\hline
\end{tabular}

Keterangan:

\section{HASIL DAN PEMBAHASAN}

\section{Gambaran Umum Harga Saham, PDB, dan Rasio Keuangan Perusahaan Big-Cap Sektor Properti Tahun 2020}

Pada Gambar 2 terlihat bahwa terjadi fluktuasi pada harga saham perusahaan-perusahaan Big-Cap sektor properti pada triwulan I-IV tahun 2020. Sepanjang periode penelitian, perusahaan BSDE, CTRA, DMAS, dan JRPT cenderung mengalami peningkatan pada harga sahamnya. Sedangkan harga saham perusahaan DUTI, PWON, SMRA, PTPP, WIKA, dan WSKT memiliki pola yang sama, yaitu mengalami peningkatan pada triwulan II, kemudian menurun cukup dalam pada triwulan III dan meningkat kembali pada triwulan IV. 


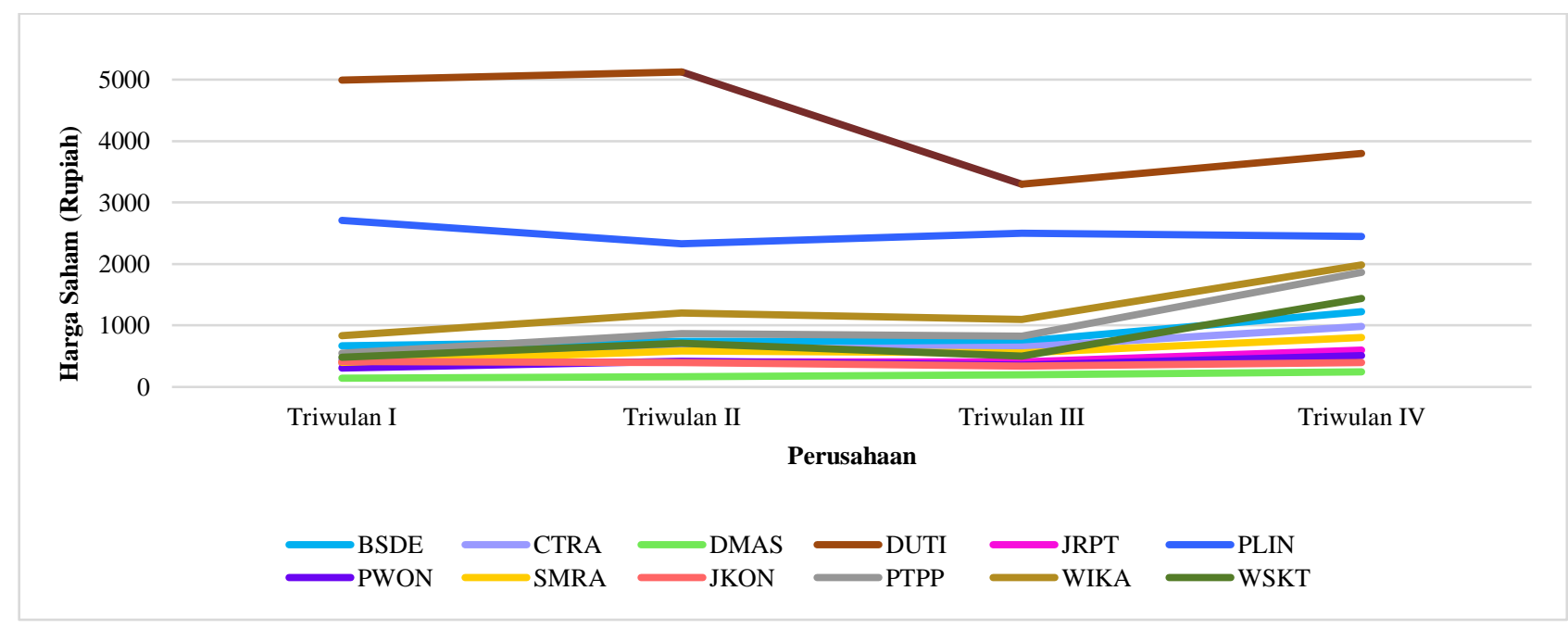

Sumber: IDX Quarterly Statistics 2020, diolah.

Gambar 2. Gambaran harga saham perusahaan Big-Cap sektor properti tahun 2020.

Pada Gambar 3 terlihat bahwa terjadi fluktuasi pada PDB triwulan I-IV tahun 2020.Rata-rata PDB pada tahun 2020 sebesar Rp2.680,561 triliun, dimana nilai PDB pada triwulan II merupakan nilai terendah dan nilai tertinggi pada triwulan III.

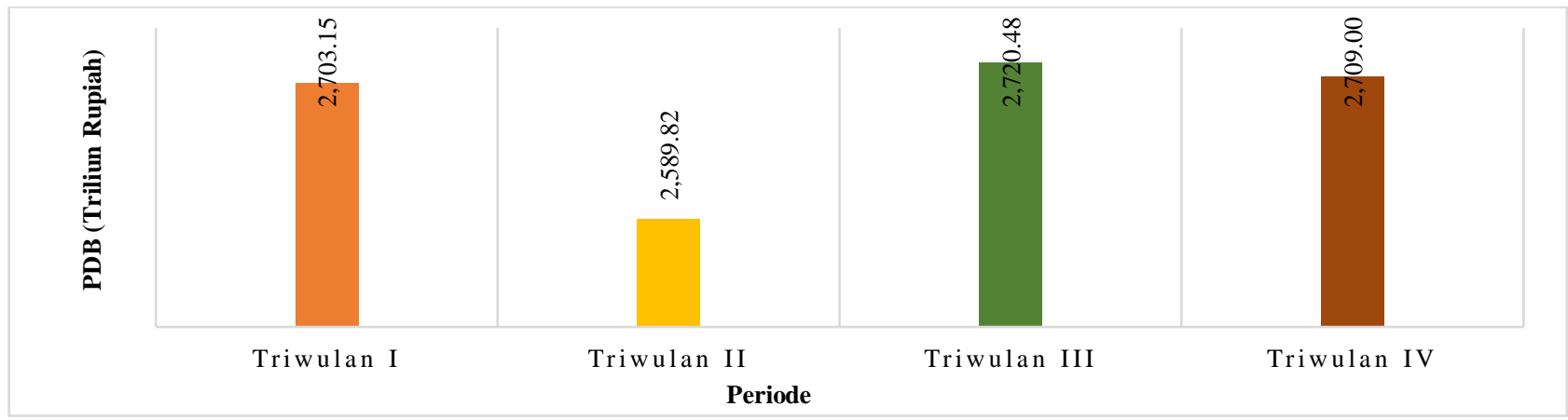

Sumber: Badan Pusat Statistik, diolah.

Gambar 3. Gambaran PDB tahun 2020.

Gambar 4 menunjukkan gambaran umum setiap variabel rasio keuangan pada masing-masing perusahaan Big-Cap sektor properti, serta pergerakan rata-ratanya pada triwulan I-IV tahun 2020. Variabel CR memiliki nilai rata-rata secara keseluruhan sebesar 196,706 persen, dimana terdapat 6 perusahaan dengan nilai rata-rata CR dibawah rata-rata tersebut. Nilai rata-rata CR terendah dimiliki oleh perusahaan WSKT, sedangkan perusahaan DUTI memiliki nilai rata-rata CR tertinggi. Nilai rata-rata secara keseluruhan variabel DER sebesar 182,523 persen dan terdapat 4 perusahaan yang memiliki nilai rata-rata DER diatas rata-rata tersebut. Perusahaan PLIN memiliki rata-rata nilai DER terendah, sedangkan perusahaan WSKT memiliki nilai ratarata DER tertinggi. Secara keseluruhan, ROE memiliki nilai rata-rata sebesar -0,127 persen, dimana terdapat 2 perusahaan dengan rata-rata ROE bernilai negatif. Nilai rata-rata ROE terendah dimiliki oleh perusahaan WSKT, sedangkan DMAS merupakan perusahaan dengan nilai rata-rata ROE tertinggi. Selanjutnya, nilai ratarata secara keseluruhan variabel PBV sebesar 182,523 persen, dimana terdapat dua perusahaan yang memiliki nilai rata-rata PBV yang dibawah rata-rata tersebut.Perusahaan PTPP memiliki rata-rata nilai PBV terendah, sedangkan perusahaan JKON memiliki nilai rata-rata PBV tertinggi. 

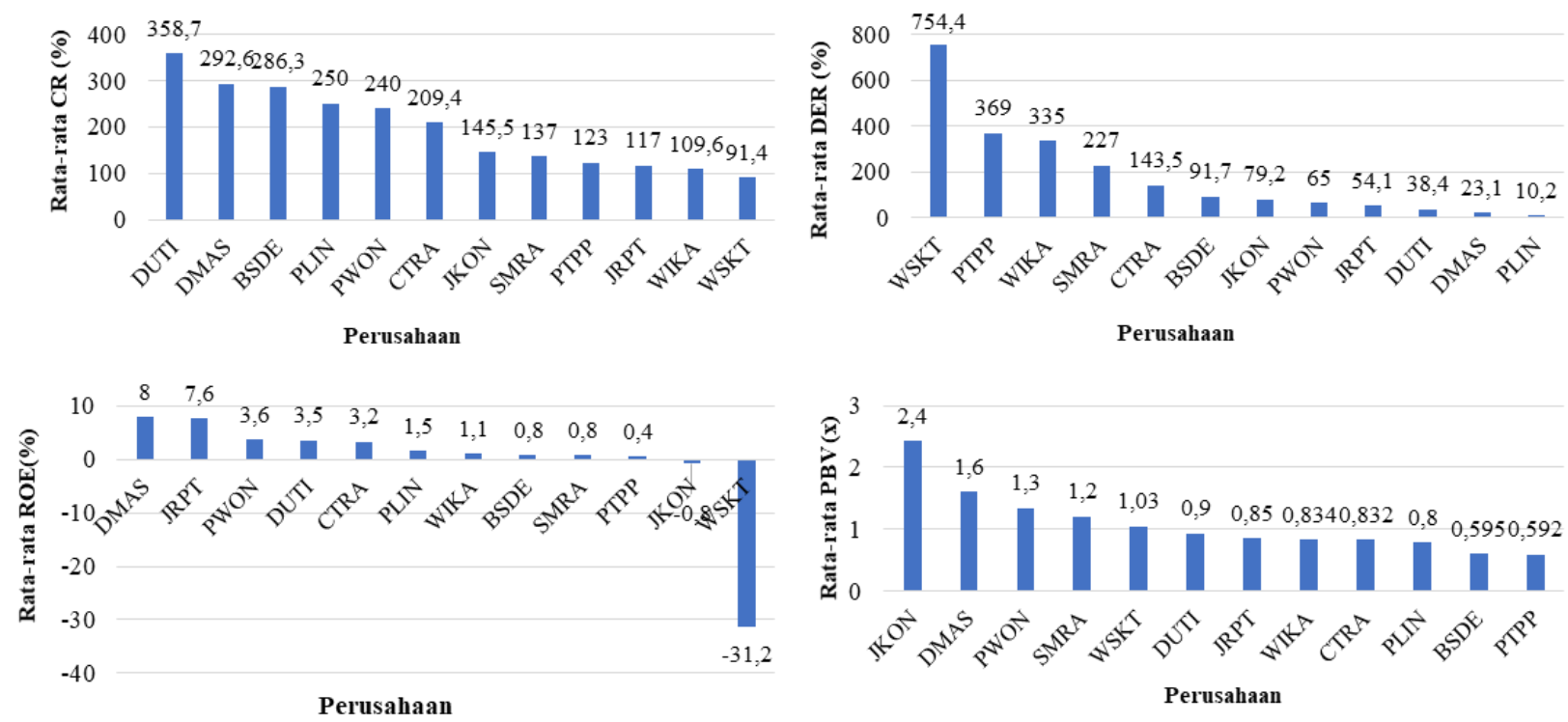

Sumber: Laporan keuangan perusahaan, diolah.

Gambar 4. Rata-rata setiap rasio keuangan per perusahaan tahun 2020.

\section{Estimasi Model Regresi Data Panel}

Pemilihan model estimasi dilakukan dengan menggunakan pengujian secara formal. Hasil pengujian untuk masing-masing uji ditunjukkan pada tabel 1.

Tabel 1. Hasil uji Chow dan uji Hausman.

\begin{tabular}{ccc}
\hline Uji & Statistik Uji & $p$-value \\
\hline Chow & $\mathrm{F}=236,116$ & 0,0000 \\
Hausman & $m=22,849$ & 0,0004 \\
\hline
\end{tabular}

Tabel 1 menunjukkan hasil pengujian dengan uji Chow, dimana $p$-value sebesar 0,0000, lebih kecil dari taraf signifikansi yang digunakan (5 persen), sehingga keputusannya adalah $\mathrm{H}_{0}$ ditolak dan dapat disimpulkan bahwa FEM lebih baik untuk digunakan. Oleh karena FEM yang terpilih pada uji Chow, maka uji BP-LM tidak perlu dilakukan. Setelah itu, pengujian model terbaik dilanjutkan dengan menggunakan uji Hausman dimana $p$-value yang dihasilkan oleh uji ini sebesar 0,0004. Nilai tersebut lebih kecil dari taraf signifikansi yang digunakan (5 persen). Oleh sebab itu, keputusannya adalah $\mathrm{H}_{0}$ ditolak, sehingga FEM lebih baik untuk digunakan. Pengujian model terbaik menggunakan uji Chow dan uji Hausman sama-sama menunjukkan bahwa FEM adalah model terbaik yang dapat digunakan.

\section{Pengujian Asumsi Struktur Variance-Covariance Residual}

Oleh karena FEM adalah model yang terpilih, maka perlu dilakukan pengujian asumsi pada matriks variance-covariance untuk menghindari bias pada estimasi FEM akibat adanya sifat heteroskedastis dan adanya korelasi cross-sectional. Pengujian dilakukan dengan menggunakan uji LM dan $\lambda$ LM. Hasil pengujian untuk setiap uji ditunjukkan pada tabel 2 .

Tabel 2. Hasil uji LM dan $\lambda$ LM.

\begin{tabular}{ccc}
\hline Uji & Statistik Uji & Titik kritis \\
\hline $\mathrm{LM}$ & $\mathrm{LM}=23,01711$ & $\chi_{(0,05 ; 11)}^{2}=4,574813$ \\
$\lambda \mathrm{LM}$ & $\lambda \mathrm{LM}=124,4034$ & $\chi_{(0,05 ; 66)}^{2}=48,30538$ \\
\hline
\end{tabular}

Tabel 2 menunjukkan hasil pengujian dengan uji LM, dimana nilai statistik uji LM yang dihasilkan lebih besar dari $\chi_{(0,05 ; 11)}^{2}$, sehingga keputusannya adalah $\mathrm{H}_{0}$ ditolak dan dapat disimpulkan bahwa struktur matriks variance-covariance residual bersifat heteroskedastis. Selanjutnya dilakukan uji $\lambda \mathrm{LM}$, dimana nilai statistik uji LM yang dihasilkan lebih besar dari $\chi_{(0,05 ; 66)}^{2}$, sehingga keputusannya adalah $\mathrm{H}_{0}$ ditolak dan dapat 
disimpulkan bahwa terdapat korelasi antarindividu. Oleh karena struktur matriks variance-covariance bersifat heteroskedastis dan terdapat cross-sectional correlation, maka model yang tepat adalah FEM Seemingly Unrelated Regression (SUR) dengan Feasible Generalized Least Square (FGLS) sebagai metode estimasi parameternya.

\section{Pengujian Asumsi Klasik}

Setelah memeroleh model yang terbaik, yaitu FEM SUR, dilakukan pengujian asumsi klasik pada model. Penggunaan model SUR sudah mampu mengatasi masalah pelanggaran asumsi heteroskedastis dan adanya autokorelasi pada model. Oleh sebab itu, uji asumsi klasik pada model yang perlu dilakukan adalah uji asumsi normalitas dan nonmultikolinieritas (Ekananda, 2016).

Tabel 3. Hasil uji asumsi normalitas.

\begin{tabular}{ccc}
\hline Uji & Statistik Uji & $p$-value \\
\hline Asumsi Normalitas & $\mathrm{JB}=1,380627$ & 0,501419 \\
\hline
\end{tabular}

Tabel 3 menunjukkan hasil pengujian dengan uji Jarque-Bera, dimana diperoleh $p$-value sebesar 0,5014 lebih besar dari taraf signifikansi lima persen. Oleh sebab itu, keputusannya adalah $\mathrm{H}_{0}$ gagal ditolak, sehingga kesimpulannya residual pada model berdistribusi normal.

Tabel 4. Nilai VIF setiap variabel independen.

\begin{tabular}{cc}
\hline Variabel & VIF \\
\hline lnPDB & 2,596136 \\
CR & 3,586993 \\
DER & 6,072654 \\
ROE & 4,616197 \\
PBV & 9,491569 \\
\hline
\end{tabular}

Tabel 4 menunjukkan nilai VIF untuk setiap variabel independen. Nilai VIF seluruh variabel independen lebih kecil dari 10, sehingga dapat disimpulkan bahwa asumsi nonmultikolinieritas pada model terpenuhi.

\section{Pengujian Keberartian Model}

Model terbaik yang digunakan dalam penelitian ini adalah FEM SUR. Tabel 5 menunjukkan ringkasan hasil estimasi model yang telah terbentuk.

Tabel 5. Hasil estimasi model FEM SUR.

\begin{tabular}{lllll}
\hline Variable & Coefficient & Std. Error & $t$-Statistic & Prob. \\
\hline C & 5,049232 & 2,987313 & 1,690225 & 0,1010 \\
lnPDB & 0,075609 & 0,203079 & 0,372315 & 0,7122 \\
CR & $-0,000389$ & 0,000367 & $-1,061325$ & 0,2967 \\
DER & $-0,003196$ & 0,000413 & $-7,743690$ & 0,0000 \\
ROE & $-0,007557$ & 0,002236 & $-3,395461$ & 0,0019 \\
PBV & 1,022547 & 0,045027 & 22,70983 & 0,0000 \\
\hline
\end{tabular}

Keterangan: Variabel independen yang digunakan adalah InHargaSaham

Persamaan yang terbentuk adalah sebagai berikut.

$\operatorname{lnHargaSaham}_{l t}=\left(5,049232+\mu_{i}\right)+0,075609 \ln P D B_{i t}-0,000389 C R_{i t}-0,003196 D E R_{i t}{ }^{*}-$

$0,007557 R O E_{i t}{ }^{*}+1,022547 P B V_{i t}{ }^{*}$

Keterangan:

*: signifikan pada taraf signifikansi lima persen

Prob(F-statistics): 0,000000

Adjusted R-squared: 0,995917

Nilai adjusted R-squared yang dihasilkan oleh model adalah sebesar 0,995917. Hal ini menunjukkan variabel independen dapat menjelaskan variasi harga saham sebesar 99,5917 persen dan sisanya 0,4083 persen dijelaskan oleh variabel di luar model. Uji F (simultan) menghasilkan nilai Prob(F-statistics) sebesar 0,00000. Nilai tersebut lebih kecil dari tingkat signifikansi lima persen, sehingga tolak $\mathrm{H}_{0}$. Oleh sebab itu, minimal 
terdapat satu variabel independen yang signifikan memengaruhi harga saham. Selanjutnya, untuk mengetahui pengaruh masing-masing variabel independen secara parsial, maka dilakukan uji $t$. Hasil uji tersebut ditunjukkan pada Tabel 5, dimana nilai $\mid$ t-statistics $\mid$ untuk setiap variabel independen dibandingkan dengan titik kritis, yaitu $t_{(0,05 ; 31)}=1,69552$. Berdasarkan hasil pengujian, dapat disimpulkan bahwa variabel rasio keuangan perusahaan, yaitu PBV berpengaruh secara positif dan signifikan terhadap harga saham. Sedangkan variabel rasio keuangan perusahaan yang berpengaruh secara negatif dan signifikan terhadap harga saham adalah variabel DER dan ROE. Variabel CR dan PDB tidak signifikan memengaruhi harga saham.

Variabel DER signifikan berpengaruh negatif terhadap harga saham. Pengaruh negatif dari DER dapat menjadi sinyal bagi investor-investor dalam berinvestasi. DER yang tinggi menunjukkan resiko yang tinggi bagi para investor (Sartono, 2014). Hal ini disebabkan oleh tingginya DER berarti aktiva perusahaan yang dibiayai oleh utang tinggi, sehingga laba yang diperoleh akan digunakan untuk keperluan membayar utang dan laba yang dibagi untuk investor akan kecil atau perusahaan tidak membagi labanya sama sekali. Hal ini dapat memberikan sinyal negatif bagi investor dan mengurangi minat investor terhadap saham tersebut, sehingga permintaan terhadap saham tersebut akan turun dan harga saham tersebut ikut menurun. Penelitian yang dilakukan oleh Rahmatullah, Ahmad, dan Rahayu (2019) juga memberikan hasil yang sama dengan penelitian ini.

Variabel ROE signifikan berpengaruh negatif terhadap harga saham. Pengaruh negatif dari ROE menunjukan buruknya kinerja perusahaan akibat laba yang dihasilkan tidak optimal karena perusahaan tidak mampu mengelola modalnya dengan efisien (Indrawati, Darmayanti, dan Syukur, 2016). Pada masa pandemi akibat COVID-19, laba yang diperoleh perusahaan-perusahaan yang diteliti secara rata-rata turun drastis dibandingkan periode sebelumnya akibat terganggunya aktivitas ekonomi di masyarakat. Meningkatnya harga saham saat ROE menurun dapat disebabkan oleh banyaknya sentimen positif yang menimbulkan optimisme investor pada perusahaan sektor properti, sehingga permintaan terhadap saham perusahaan sektor properti meningkat dan harga saham pun ikut meningkat. Beberapa kebijakan pemerintah untuk mendukung sektor properti di tengah kondisi pandemi dapat memberikan sentimen positif bagi investor, sehingga penurunan laba bersih perusahaan tidak memengaruhi investor dalam berinvestasi. Selain itu adanya berita mengenai pembentukan Sovereign Wealth Fund (SWF) asli Indonesia bernama Investment Authority (INA) juga memberikan sentimen positif kepada investor, dimana dana investasi ini akan diberikan kepada perusahaanperusahaan BUMN, khususnya akan digunakan untuk pembangunan infrastruktur, berupa jalan tol dan bandar udara demi mendukung Proyek Strategis Nasional (PSN). Sebagian besar proyek jalan tol tersebut dimiliki oleh perusahaan konstruksi BUMN yang termasuk ke dalam perusahaan Big-Cap sektor properti, seperti WSKT, WIKA, dan PTPP. Penelitian Indrawati, Darmayanti, dan Syukur (2016) juga memberikan hasil yang sama dengan penelitian ini.

Variabel PBV signifikan berpengaruh positif terhadap harga saham. Nilai koefisien variabel sebesar 1,022547 berarti bahwa dengan tingkat signifikansi 5 persen, setiap kenaikan PBV sebesar satu kali, akan meningkatkan harga per lembar saham sebesar 1,022547 persen, dengan asumsi variabel lain dianggap tetap. PBV perusahaan akan meningkat seiring dengan peningkatan nilai perusahaan tersebut. Peningkatan nilai perusahaan tersebut menunjukkan keberhasilan perusahaan dalam menciptakan nilai bagi pemegang sahamnya. Nilai PBV suatu perusahaan yang meningkat dapat menjadi sinyal positif untuk investor, sehingga permintaan investor terhadap saham tersebut dapat meningkat. Peningkatan permintaan tersebut dapat menaikkan harga saham pada bursa. Penelitian Sufyati dan Rachmawati (2020) juga memberikan hasil yang sama dengan penelitian ini.

Tabel 6. Intercept setiap perusahaan Big-Cap sektor properti.

\begin{tabular}{cc}
\hline Perusahaan & Intercept \\
\hline BSDE & 5,266826 \\
CTRA & 5,008752 \\
DMAS & 2,522574 \\
DUTI & 6,376664 \\
JRPT & 4,296927 \\
PLIN & 5,855348 \\
PWON & 3,657492 \\
SMRA & 4,796804 \\
JKON & 2,493560 \\
PTPP & 6,502819 \\
WIKA & 6,384593 \\
WSKT & 6,926233 \\
\hline
\end{tabular}


Tabel 6 menunjukkan estimasi intercept untuk setiap perusahaan Big-Cap sektor properti periode triwulan I-IV tahun 2020. Nilai intercept terbesar dimiliki oleh perusahaan WSKT dengan intercept sebesar 6,926233. Nilai tersebut berarti perusahaan WSKT memiliki harga saham tertinggi dibandingkan perusahaan lainnya dengan asumsi seluruh variabel bernilai nol. Selanjutnya, perusahaan dengan nilai intercept yang terendah adalah JKON dengan nilai intercept sebesar 2,49356. Nilai tersebut berarti perusahaan JKON memiliki harga saham terendah dibandingkan perusahaan lainnya dengan asumsi seluruh variabel bernilai nol.

\section{KESIMPULAN}

Kesimpulan dari penelitian ini berdasarkan hasil dan pembahasan yang telah dijabarkan sebelumnya, yaitu pada periode triwulan I-IV tahun 2020, pergerakan harga saham perusahaan-perusahaan Big-Cap sektor properti mengalami fluktuasi dan terjadi penurunan pada triwulan III, namun meningkat cukup signifikan pada triwulan IV tahun 2020. Sedangkan PDB mengalami penurunan yang cukup signifikan pada triwulan II, namun kembali meningkat pada triwulan-triwulan selanjutnya. Terdapat beberapa perusahaan dengan nilai rata-rata rasio keuangan diatas atau dibawah nilai rata-rata secara keseluruhan. Selain itu, penelitian menggunakan FEM SUR ini memberikan hasil bahwa dengan tingkat kepercayaan 95 persen, dapat disimpulkan PBV siginifikan berpengaruh positif, sedangkan DER dan ROE signifikan berpengaruh negatif terhadap harga saham perusahaan Big-Cap sektor properti periode triwulan I-IV tahun 2020. CR dan PDB tidak memberikan pengaruh yang signifikan terhadap harga saham perusahaan Big-Cap sektor properti pada periode penelitian.

Saran yang dapat diberikan berdasarkan kesimpulan adalah investor yang akan berinvestasi pada saham perusahaan-perusahaan Big-Cap sektor properti pada masa pandemi, sebaiknya memperhatikan nilai rasio keuangan PBV, DER, dan ROE yang berpengaruh terhadap harga saham sebelum mengambil keputusan berinvestasi. Untuk perusahaan-perusahaan Big-Cap sektor properti, sebaiknya mampu meningkatkan kinerja perusahaannya dengan melakukan evaluasi terhadap hal-hal yang terkait dengan rasio DER, ROE, dan PBV perusahaan, sehingga minat investor dalam berinvestasi pada saham perusahaan tersebut akan lebih meningkat dan harga saham juga dapat meningkat. Peneliti yang tertarik dengan penelitian sejenis disarankan untuk menambah variabel-variabel lain, baik dari sisi rasio keuangan perusahaan, maupun ekonomi makro. Selain itu dapat pula menggunakan metode analisis yang berbeda, sehingga pembahasan penelitian selanjutnya akan lebih baik.

\section{DAFTAR PUSTAKA}

Ahman, E. \& Indriani, E. (2007). Membina Kompetensi Ekonomi: Buku Pelajaran untuk SMA/MA Kelas XI Program Ilmu Pengetahuan Sosial. Bandung: Grafindo Media Pratama.

Azis, M., Mintarti, S., dan Nadir, M. (2015). Manajemen Investasi Fundamental, Teknikal, Perilaku Investor dan Return Saham. Yogyakarta: Deepublish.

Ekananda, M. (2016). Analisis Ekonometrika Data Panel. Jakarta: Mitra Wacana Media.

Franita, Riska. (2018). Mekanisme Good Corporate Governance dan Nilai Perusahaan: Studi untuk Perusahaan Telekomunikasi. Medan: Lembaga Penelitian dan Penulisan Ilmiah AQLI.

Gujarati, D. N. (2004). Basic Econometrics, Fourth Edition. Singapore: The McGraw-Hill Companies

Greene, W. H. (2003). Econometric Analysis. Upper Saddle River, N.J: Prentice Hall.

Hadiwardoyo, W. (2020). Kerugian Ekonomi Nasional Akibat Pandemi COVID-19. Baskara Journal of Business \& Entrepreneurship, 2(2), 83-92

Indrawati, L., Darmayanti, N., dan Syukur, A. S. (2016). Pengaruh Earning Per Share (EPS), Return on Equity (ROE), Return on Assets (ROA), dan Net Profit Margin (NPM) terhadap Harga Saham. Prosiding SNA MK, 28 September 2016, 252-268.

Jones, C. P. (2012). Investment Principles and Concepts. Twelfth Edition. Singapura: John Wiley and Sons Singapore Pte. Ltd.

Kasmir. (2017). Analisis Laporan Keuangan. Jakarta: Rajawali Pers.

Rahmatullah, M. B., Ahmad, I. S., dan Rahayu, S. P. (2019). Pemodelan Harga Saham Sektor Konstruksi Bangunan, Properti dan Real Estate di JII 70 Tahun 2013-2018 Menggunakan Regresi Data Panel (FEM Cross-section SUR). Jurnal Sains dan Seni ITS, 8(2), 238-245.

Santoso, B. (2005). Prospek Kredit Properti 2005. Economic Review Journal, 199.

Sartono, R. A. (2014). Manajemen Keuangan Teori dan Aplikasi. Edisi 4. Yogyakarta: BPFE.

Sufyati \& Rachmawati, A. F. (2020). Pengaruh Faktor Fundamental terhadap Harga Saham Syariah di Jakarta Islamic Index Sektor Properti dan Real Estate, 16(1), 98-114.

Sunaryo, D. (2019). Manajemen Investasi dan Portofolio. Surabaya: CV. Penerbit Qiara Media. 
Tandelilin, E. (2010). Portofolio dan Investasi Teori dan Aplikasi. Edisi Pertama. Yogyakarta: Kanisius.

Widarjono, A. (2018). Ekonometrika Pengantar dan Aplikasinya Disertai Panduan Eviews. Yogyakarta: UPP STIM YKPN.

Zulfikar. (2016). Pengantar Pasar Modal dengan Pendekatan Statistika. Yogyakarta: Deepublish. 